\title{
PENGARUH PENGGUNAAN VIRGIN COCONUT OIL (VCO) DALAM RANSUM TERHADAP KECERNAAN ENERGI DAN PROTEIN TERNAK BABI FASE GROWER
}

\author{
Christofle Tulung $^{*}$, J.F. Umboh ${ }^{* *}$, F.N. Sompie ${ }^{* *}$, Ch.J. Pontoh ${ }^{* *}$ \\ Fakultas Peternakan Universitas Sam Ratulangi Manado 95115 \\ E-mail: chriszoldyck@yahoo.com
}

\begin{abstract}
ABSTRAK
Penggunaan VCO sebagai sumber energi tambahan, selain menambah tingkat energi ransum, juga meningkatkan efisiensi penggunaan energi ransum.Peningkatan efisiensi penggunaan energi tergantung pada daya cerna lemak.Penelitian ini bertujuan untuk mengetahui sejauh mana pengaruh tingkat penggunaan VCO dalam ransum terhadap kecernaan energi dan protein pada ternak babi. Penelitian menggunakan 20 ekor ternak babi jantan kastrasi persilangan Duroc $\mathrm{X}$ Spotted Poland China, berumur 1,5 - 2,0 bulan dengan bobot badan 32,5-41,5 kg. Penelitian ini menggunakan Rancangan Acak Lengkap dengan 5 perlakuan dan 4 ulangan. Perlakuan disusun sebagai berikut: $\mathrm{R} 0=$ Ransum kontrol $100 \%$ tanpa VCO; R1 = Ransum kontrol 99,5\% + 0,5\% VCO;R2= Ransum kontrol $99,0 \%+1,0 \%$ VCO;R3 $=$ Ransum kontrol 98,5\% + 1,5\% VCO; dan R4 $=$ Ransum kontrol 98,0 \% + 2,0\% VCO. Parameter yang diamati, yaitu tingkat kecernaan energi dan protein ransum. Hasil penelitian menunjukkan bahwa pengaruh perlakuan berbeda tidak nyata $(\mathrm{P}>0,05)$ terhadap kecernaan energi dan protein ransum. Dapat disimpulkan bahwa penambahan VCO sampai dengan $2,0 \%$ dalam ransum tidak mempengaruhi kecernaan energi dan protein ransum ternak babi fase pertumbuhan.
\end{abstract}

Kata Kunci: Virgin coconut oil (VCO), Kecernaan Energi dan protein, Ternak babi fase pertumbuhan.

\footnotetext{
*Alumni Fakultas Peternakan

** Jurusan Ilmu Nutrisi dan Makanan Ternak
}

\section{ABSTRACT}

EFFECT OF UTILIZATION OF VIRGIN COCONUT OIL (VCO) IN THE DIET ON ENERGY AND PROTEIN DIGESTIBILITY OF GROWING PIGS. Utilization of virgin coconut oil (VCO) as a source of energy, not only increase the enegy in the diet, but also increase energy utilization efficiency. The increase of energy utilization efficiency depends on fat digestibility. The present study was designed to elaborate the effect of utilization of VCO in the diets on energy and protein digestibility of growing pigs. The experiment was conducted using 20 castrated male pigs aged 6-7 weeks weighing $32.5-41.5 \mathrm{~kg}$. The data were analyzed according to the linear model procedure for ANOVA appropriate for Randomized Block Design with 5 treatments and 4 replications. Treatments were formulated as follow: $\mathrm{R} 0=$ $100 \%$ control diet $+\mathrm{VCO} ; \mathrm{R} 1=99.5 \%$ control diet $+0.5 \%$ VCO; R2 $=99 \%$ control diet + $1.0 \% \mathrm{VCO} ; \mathrm{R} 3=98.5 \%$ control diet $+1.5 \%$ $\mathrm{VCO}$; and $\mathrm{R} 4=98 \%$ control diet $+2.0 \%$ VCO. Parameters measured were: energy and protein digestibility. The result showed that the utilization ov VCO up to $4 \%$ in the diets, had no effect $(\mathrm{P}>0.05)$ on energy and protein digestibility. It can be concluded that the addition of VCO up to $2.0 \%$ in the diets has no significant influence on energy and protein digestibility of growing pigs.
Keyword : Virgin coconut oil (VCO), Energy and Protein Digestibility, Growing Pigs.




\section{PENDAHULUAN}

Lingkungan di mana ternak dipelihara mempengaruhi kehidupan dan produktifitas ternak tersebut. Di antara faktor lingkungan yang dapat dimanipulasi adalah makanan. Kebutuhan nutrien terutama protein untuk ternak babi erat kaitannya dengan ketersediaan energi, karena suhu lingkungan dan tingkat energi ransum merupakan faktor pembatas utama yang mempengaruhi tingkat konsumsi makanan. Kandungan zat-zat makanan ransum akan menentukan koefisien cerna dan metabolisme zat-zat makanan yang pada gilirannya mempengaruhi efisiensi penggunaan makanan. Tingkat energi dan sumber energi ransum juga mempengaruhi kecernaan zat-zat makanan ransum.

Penggunaan bahan makanan sumber asam lemak merupakan cara yang paling mudah untuk mempertinggi energi ransum serta menyediakan asam-asam lemak esensial. Selain itu lemak dapat meningkatkan palabilitas dan menambah efisiensi penggunaan makanan. Jagung sebagai sumber energi dalam ransum penggunaannya tidak bisa melebihi standar yang ditentukan, sehingga dibutuhkan sumber energi tambahan. Salah satu bahan makanan sumber lemak yang dapat dijadikan sebagai sumber energi tambahan dalam ransum adalah minyak kelapa atau virgin coconut oil (VCO). Virgin coconut oil dihasilkan dari ekstrak daging kelapa melalui proses tanpa pemanasan atau dengan pemanasan pada suhu rendah. Penggunaan VCO lebih bermanfaat dibandingkan minyak kelapa biasa, karena mengandung asam lemak berantai medium yang merupakan sumber energi yang siap pakai dan mudah diserap oleh tubuh.

Virgin coconut oil adalah minyak kelapa yang dihasilkan dari daging buah kelapa (Cocos Nucifera L) yang segar dan matang dengan cara mekanis atau alamiah dengan atau tanpa pemanasan, yang tidak mengakibatkan perubahan pada minyak. Minyak kelapa murni mengandung asam lemak jenuh rantai sedang (medium chain saturated fatty acid) sekitar 64\% dengan perincian lebih dari $50 \%$ asam laurat $(\mathrm{C}$ 12), 6-7\% asam kaprat (C 10), dan 8\% asam kaprilat (C 8). Virgin coconut oil sendiri sebagian besar terdiri dari asam lemak jenuh $(92 \%)$ rantai sedang (8-12 ikatan karbon) 6\% kandungan asam lemak tidak jenuh (mono unsaturated), dan $2 \%$ polyunsaturated. Sedikitnya asam lemak tidak jenuh menyebabkan VCO sangat stabil dan tahan oksidasi, sehingga sulit menjadi tengik. Asam lemak rantai medium ini merupakan sumber energi yang siap pakai dan lebih mudah diserap oleh tubuh. Untuk memanfaatkan asam lemak ini, tubuh menimbunnya dalam bentuk lemak terlebih dahulu sehingga menimbulkan kegemukan. Virgin coconut 
oil mempunyai sifat tahan terhadap panas, cahaya, oksigen, dan proses degradasi. Sifat itu membuat VCO dapat disimpan dalam jangka waktu yang lama.

Virgin coconut oil mengandung lemak yang tersusun sebagian besar oleh asam lemak rantai sedang (Medium Chain Fatty Acid atau MCFA) yang tidak berbahaya bagi tubuh. Asam lemak tersebut juga berguna untuk meningkatkan metabolisme tubuh dan menambah energi. Asam lemak yang terkandung dalam VCO pada akhirnya dalam tubuh ternak akan dikonversi menjadi produk energi, sehingga bisa bermanfaat sebagai suplemen untukmembantu mengurangi konsumsi pakan dan dapat menekan biaya produksi (pembelian pakan).

Pemberian VCO sebagai sumber energi tambahan, selain menambah tingkat energi ransum, juga meningkatkan efisiensi penggunaan energi ransum. Peningkatan efisiensi penggunaan energi tergantung dari daya cerna lemak dalam VCO. Selain itu penggunaan minyak atau lemak dilakukan untuk menghindari diubahnya protein menjadi energi, sehingga protein ransum benar-benar dapat dimanfaatkan untuk pertumbuhan secara makasimal. Virgin coconut oil sebagai pakan sumber energi tambahan dalam ransum ternak babi diharapkan dapat meningkatkan konsumsi ransum, sekaligus nilai kecernaan zat-zat makanan.

Efisiensi penggunaan energi dari lemak tergantung dari sifat lemak di mana lemak yang jenuh akan menurunkan daya cerna, sedangkan lemak tidak jenuh akan menaikkan daya cerna. Lemak mempunyai efisiensi penggunaan energi yang lebih tinggi. Ransum yang mengandung lemak memiliki "heat increament" yang lebih rendah, sehingga lebih banyak energi yang tersedia untuk dipakai.

Bertolak dari uraian di atas, penelitian ini dirancang untuk mengetahui sejauh mana pengaruh tingkat penggunaan VCO dalam ransum terhadap kecernaan energi dan protein ransum pada ternak babi fase finisher.

\section{MATERI DAN METODE PENELITIAN}

Penelitian ini dilaksanakan di Peternakan Babi milik Bapak Ronald Kalalo di Kelurahan Wailan, Kecamatan Tomohon Utara, Kota Tomohon, selama 60 hari masa pendahuluan dan 3 hari masa pengumpulan feses. Penelitian ini menggunakan 20 ekor ternak babi jantan kastrasi persilangan Duroc $\mathrm{X}$ Spotted Poland China, berumur1,5 - 2,0 bulan dengan bobot badan awal 13,0 $\pm 20 \mathrm{~kg}$ dan bobot badan akhir 30,5-41,5 $\mathrm{Kg}$. 
Tabel 1. Komposisi bahan pakan penyusun ransum dan kandungan zat-zat makanan.

\begin{tabular}{ll}
\hline Bahan Pakan & Proporsi (\%) \\
\hline Jagung & 60,0 \\
Konsentrat & 40,0 \\
\hline Total & 100 \\
\hline
\end{tabular}

\begin{tabular}{ll}
\hline Zat-Zat Makanan & Persen $(\%)$ \\
\hline Bahan Kering & 89,40 \\
Protein & 21,24 \\
Lemak & 3,54 \\
Serat kasar & 3,60 \\
\hline
\end{tabular}

Tabel 2. Kandungan zat-zat makanan ransum percobaan.

\begin{tabular}{lccccc}
\hline \multirow{2}{*}{ Zat-zat Makanan } & \multicolumn{5}{c}{ Perlakuan } \\
\cline { 2 - 6 } & RO & R1 & R2 & R3 & R4 \\
\hline Bahan Kering & 89,62 & 89,73 & 89,39 & 89,09 & 89,01 \\
Protein Kasar & 20,00 & 19,75 & 18,45 & 17,99 & 18,47 \\
Energi (GE) & 3968 & 4129 & 4110 & 4415 & 4545 \\
\hline
\end{tabular}

Dihitung berdasarkan kandungan nutrien ransum penelitian hasil analisis Laboratorium Nutrisi Ternak Ruminansia dan Kimia Makanan Ternak Fapet Unpad.

Kandang yang digunakan yaitu kandang individu (individual pen) sebanyak 20 unit dengan ukuran $1,5 \times 1 \times 80 \mathrm{~cm}$. Lantai kandang terbuat dari beton dan antara unit satu dan unit yang lain dipisahkan dengan dinding kayu. Setiap kandang dilengkapi tempat makan dan minum yang terbuat dari beton berukuran $30 \mathrm{~cm}$ x $30 \mathrm{~cm}$ x 10 cm. Peralatan yang digunakan dalam penelitian ini, yaitu timbangan dengan beberapa kapasitas untuk menimbang bahan pakan, feses, dan bobot ternak babi; kantong feses, pipet ukur $100 \mathrm{ml}$, thermometer, dan kantong plastik.

Bahan pakan penyusun ransum dasar (R0) diformulasi dan disesuaikan dengan bahan yang tersedia. Pada ransum dasar (R0) ini, kemudian ditambahkan VCO dengan beberapa tingkatan. Virgin coconut oil yang digunakan dalam peneliitian ini yakni VCO dengan merek dagang Healtrhiest produksi Sari Alam Nusantara, Tumaluntung, Minahasa Utara. Komposisi bahan pakan penyusun ransum R0 serta zat-zat makanan dapat dilihat pada Tabel 1, sedangkan komposisi zat makanan ransum perlakuan disajikan pada Tabel 2. Penelitian ini menggunakan Rancangan Acak Lengkap (Steel and Torrie, 1991) dengan 5 perlakuan dan 4 ulangan. Perlakuan disusun sebagai berikut: 
R0: Ransum kontrol $100 \%$ tanpa VCO

R1: Ransum kontrol $99 \%+0,5 \%$ VCO

R2: Ransum kontrol $98 \%+1,0 \%$ VCO

R3: Ransum kontrol $97 \%+1,5 \%$ VCO

R4: Ransum kontrol $96 \%+2,0 \%$ VCO.

Penentuan konsentrasi VCO yang diberikan mengacu pada modifikasi tabel dari Lawrence and Bacharach (1964), tentang dosis/konsentrasi VCO yang aman bagi manusia dan sesuai rekomendasi Fife (2004) yaitu dosis rata-rata orang dewasa yang dianjurkan ialah 3.5 sendok makan sehari (ukuran sendok setara dengan 15 $\mathrm{mL})$.

Pada awal masa pendahuluan, semua ternak percobaan diberi obat cacing untuk membebaskan ternak babi dari pengaruh cacing atau parasit usus.Kemudian dilanjutkan dengan pemberian obat diare. Makanan dan air minum diberikan secara ad libitum. Makanan diberikan sedikit demi sedikit agar tidak tercecer. Makanan diberikan setiap hari dimulai dari jam 08.00 pagi sesudah kandang dibersihkan. Pada akhir periode penelitian, yaitu 3 hari sebelum masa pengumpulan feses, pakan yang diberikan pada ternak babi sebanyak $80 \%$ dari jumlah konsumsi sebelumnya untuk digunakan dalam pengukuran kecernaan zat-zat makanan. Selama 3 hari berturutturut, yaitu pada akhir percobaan dilakukan pengumpulan feses. Semua ternak percobaan dikenakan kantong penampung feses (fecal bag) agar feses tidak tercemar dengan kotoran atau urine. Semua feses yang didefikasi setiap saat oleh setiap ekor sejak pukul 08.00 sampai besok harinya (24 jam) ditimbang untuk menentukan jumlah feses harian yang didefikasi setiap ternak.

Sampel feses segar yang tidak terkontaminasi diambil setiap saat sebanyak $10 \%$ dari jumlah feses yang didefikasi setiap saat oleh setiap ekor lalu diberikan larutan $\mathrm{H}_{2} \mathrm{SO}_{4} \quad 2,5 \%$ untuk mengikat nitrogen agar tidak hilang waktu dikeringkan. Feses yang sudah terkumpul kemudian dikeringkan dalam oven dengan suhu $600^{\circ} \mathrm{C}$ selama 48 jam. Pada akhir percobaan jumlah feses yang didefikasi (gram.ekor ${ }^{-1} \cdot$ hari $^{-1}$ ) dan jumlah feses segar $\left(\right.$ gram.ekor $^{-1} \cdot$ hari $^{-1}$ ) serta jumlah sampel feses kering oven (gram.ekor ${ }^{-1}$ hari $^{-1}$ ) dapat diketahui. Data nilai kecernaan energi dan protein diperoleh dari sampel feses kering oven per hari yang diambil secara komposit dari setiap ekor, kemudian dianalisis di laboratorium.

\section{HASIL DAN PEMBAHASAN}

Hasil penelitian tentang pengaruh penggunaan VCO dalam ransum terhadap kecernaan energi dan protein ternak babi fase grower, dapat dilihat pada Tabel 3 . 
Tabel 3. Rataan kecernaan energi dan protein ransum ternak babi fase grower

\begin{tabular}{lccccc}
\hline \multirow{2}{*}{ Kecernaan } & \multicolumn{5}{c}{ Perlakuan } \\
\cline { 2 - 6 } & RO & R1 & R2 & R3 & R4 \\
\hline Energi (\%) & 80.20 & 79.55 & 78.96 & 80.46 & 82.73 \\
Protein (\%) & 83.96 & 81.19 & 79.69 & 78.79 & 79.48 \\
\hline
\end{tabular}

\section{Kecernaan Energi}

Data kecernaan energi dalam penelitian ini (Tabel 3) menunjukan bahwa kecernaan energi yang tertinggi pada perlakuan R4 yaitu sebesar $82,73 \%$, dan paling rendah pada perlakuan R2 yaitu sebesar 78,96\%. Kisaran angka kecernaan energi dalam penelitian ini $(78,96-$ $82,73 \%$ ) masih berada dalam kisaran sesuai rekomendasi berbagai sumber, dimana angka kecernaan energi yang normal pada ternak babi yaitu berkisar antara 70- 90\% (Tillman et al., 1991; Baker, et al., 1997; Sihombing, 1997).

Secara teori, dari berbagai sumber menyatakan bahwa semakin tinggi pemberian minyak kelapa atau VCO yang kaya energi, dalam ransum akan menekan konsumsi yang dengan sendirinya semakin rendah jumlah ransum yang terkonsumsi. Retensi makanan dalam saluran pencernaan semakin tinggi, penetrasi enzim pencernaan keseluruh bagian makanan semakin luas, akibatnya semakin tinggi pula kecernaan nutrien ransum terutama protein dan energi. Banyaknya ransum yang dikonsumsi akan disesuaikan dengan kandungan energi ransum serta tingkat kecernaannya juga akan menyesuaikan dengan energi ransum tersebut (Talumewo, 1986; Tillman et al., 1991; Sihombing, 1997).

Berdasarkan berbagai pendapat dan teori tersebut di atas, angka kecernaan energi dalam penelitian ini juga seharusnya akan meningkat dengan semakin meningkatnya penaggunaan VCO dalam ransum. Hasil analisis keragaman penelitian ini menunjukkan bahwa penggunaan VCO sampai dengan $2 \%$ dalam ransum tidak menyebabkan perbedaan secara nyata $(\mathrm{P}>0,05)$ kecernaan energi pada ternak babi fase grower yang digunakan sebagai ternak percobaan dalam penelitian ini. Tidak adanya perbedaan yang nyata angka kecernaan energi dalam penelitian ini diduga ada hal atau fakta lain sebagai penyebabnya yang belum dapat terungkap lewat penelitian ini.

Suhu lingkungan tempat penelitian ini dilakukan yaitu antara $22-27^{\circ} \mathrm{C}$ pada pagi hingga sore hari dan $16-22^{\circ} \mathrm{C}$ pada malam hingga pagi hari. Kisaran tersebut masih berada pada thermoneutral zone bagi ternak babi, sehingga diduga belum 
memberikan efek negatif terhadap metabolisme energi. Kemungkinan hasil penelitian ini akan berbeda apabila dilakukan di lingkungan yang lebih panas, karena VCO memiliki 'heat increment' yang rendah akan menyebabkan lebih terlihat efeknya terhadap metabolisme lemak atau energi, termasuk kecernaan energi. Talumewo (1986) menyatakan bahwa lemak atau minyak memiliki heat increment yang rendah dibandingkan dengan sumber energi lain seperti karbohidrat, dan heat increment yang rendah ini akan sangat membantu ternak babi yang dipelihara di lingkungan yang panas dalam mengurangi beban panas tubuh.

Kecernaan energi yang berbeda tidak nyata $(\mathrm{P}>0,05)$ pada penelitian ini dapat diduga juga disebabkan karena energi yang dihasilkan oleh metabolisme sebagian besar diperoleh dari asam lemakVCO. Kecernaan yang tidak berubah / berbeda atau tetap bisa diartikan juga bahwa adanya VCO dalam pakan tidak terlalu berpengaruh terhadap palatabilitas pakan. Hal ini bisa dibuktikan apabila dilakukan analisa kadar glukosa darah. Peningkatan glukosa darah dapat mempengaruhi konsumsi pakan, yaitu bila glukosa darah dalam sel cukup maka konsumsi pakan akan menurun karena energi yang tersedia masih banyak (Fife, 2001).

\section{Kecernaan Protein}

Data pada Tabel 4 memperlihatkan bahwa kecernaan protein berkisar antara $78,79-83,96 \%$. Kisaran tersebut masih berada dalam kisaran standar kecernaan yang direkomendasikan oleh Sihombing (1997), bahwa kecernaan protein babi grower berkisar 75- 90\%. Angka kecernaan protein dalam penelitian ini juga berada pada kisaran sebagaimana direkomendasikan yaitu 70-90\% (Tilman et al., 1991; Backer, et al., 1997; dan Pelealu, 2009).

Hasil analisis keragaman nilai kecernaan protein dalam penelitian ini menunjukkan angka yang berbeda tidak nyata $(\mathrm{P}>0,05)$ antar perlakuan yang diteliti. Wuisan (1993) meneliti penggunaan minyak kelapa dalam ransum ternak babi dengan penambahan beberapa level minyak kelapa yaitu: 2, 4, 6, dan $8 \%$ ternyata tidak meningkatkan secara nyata $(\mathrm{P}>0,05)$ kecernaan protein.

Wuisan (1993) menyatakan bahwa, penambahan lemak dengan sumber asam lemak jenuh dalam ransum akan menurunkan penyerapan zat-zat makanan termasuk protein. Selanjutnya dikatakan, bahwa kekurangan asam lemak jenuh dalam ransum akan menurunkan kecepatan pertumbuhan yang terutama ditentukan oleh banyak atau sedikitnya protein yang diserap. Hasil penelitian Yahya et al. 
(1999) menunjukan bahwa penambahan minyak kelapa (sumber asam lemak jenuh) dalam ransum sebagai sumber energi sampai pada level $8 \%$ memberikan kecernaan protein yang tidak berbeda nyata $(\mathrm{P}>0,05)$ dibanding perlakuan dengan penambahan minyak kelapa $0,2,4$, dan $6 \%$ dalam ransum.

Ranjhan (1980) menyatakan bahwa kecernaan protein tergantung pada kandungan protein di dalam ransum. Ransum yang mengandung protein rendah mempunyai kecernaan yang rendah pula. Kandungan protein masing-masing ransum perlakuan dalam penelitian ini sama yaitu $15,95 \%$ (iso protein), sehingga tidak turut mempengaruhi nilai kecerenaan protein ransum. Sebagaimana yang dinyatakan Ranjhan (1980) tersebut, penambahan VCO sampai 2,0\% dalam ransum ternyata tidak mempengaruhi kecernaan protein ransum dalam penelitian ini. Angka konsumsi ransum (bahan kering) yang hampir sama dalam penelitian ini juga turut memberikan andil tidak berbedanya kecernaan protein dalam penelitian ini. Lebih lanjut Tilman et al.,(1991); Nair, et al., (1999) mengemukakan bahwa semakin banyak bahan makanan yang dicerna maka ruang yang tersedia untuk penambahan makanan dalam usus halus akan lebih banyak pula. Kecernaan pakan sangat dipengaruhi oleh komposisi pakan, jumlah pakan, penyimpanan dan jenis ternak.
Menurut NRC (1988), faktor yang mempengaruhi konsumsi pakan adalah palatabilitas ransum, temperatur, kelembaban, kesehatan ternak, genetik, pengolahan pakan dan ketersediaan air. Suhu lingkungan tempat penelitian ini dilakukan, yaitu berkisar antara $22-27^{\circ} \mathrm{C}$ pada pagi hingga sore hari dan $16-22^{\circ} \mathrm{C}$ pada malam hingga pagi hari. Kisaran temperatur tersebut masih berada pada thermoneutral zone $\left( \pm 21,0^{\circ} \mathrm{C}\right)$ bagi ternak babi, sehingga diduga belum memberikan efek negatif terhadap metabolisme protein.

\section{KESIMPULAN}

Penambahan virgin coconut oil (VCO) sampai dengan 2,0\% dalam ransum tidak mempengaruhi kecernaan energi dan protein ternak babi fase pertumbuhan.

\section{SARAN}

Perlu penelitian lebih lanjut untuk melihat efek penambahan VCO dalam ransum ternak yang dipelihara di daerah dengan suhu lingkungan yang panas.

\section{DAFTAR PUSTAKA}

Baker, D.H., R.A. Easter., M. Ellis., J.L. Beverly, and G.R. Hollis. 1997. Nutrient Allowances For Swine. Dept. of Animal Sciences, Univ. of Illinois, Urbana, IL. 
Fife, B. 2001, Diabetes and Virgin Coconut Oil http://www.coconutconnections.co m/index. htm, 13 April 2008.

Nair, K.G.P., T. Rajamohan and P.A Kurup.1999. Coconut Kernel Protein Modifies the Effect of Coconut Oil on Serum Lipids. Plant Foods Hum Nutr 53:133144.

NRC. 1988. Nutrient Requirements of Swine. Ninth Revised Edition. Nutrient Requirements of Domestic Animals. National Academy Press.Washington,D.C.

Pelealu, I. 2009. Efek Pemberian Konsentrat Pabrikan dan Buatan Sendiri Terhadap Kecernaan Protein Dan Energi Ternak Babi Fase Grower [Skripsi]. Fakultas Peternakan Universitas Sam Ratulangi Manado.

Ranjhan S. K. 1980. Animal Nutrition in The Tropics. Vikas Publishing House P and T Ltd. New Delhi.

Sihombing, D.T.H. 1997. Ilmu Ternak Babi. University Gadjah Mada Press. Yogyakarta.

Steel, R. G. D dan J. H Torrie. 1991.
Prinsip dan Prosedur Statistika. Gramedia Pustaka Utama. Jakarta.

Talumewo, J. 1986. Efek Pemberian Ransum Dengan Berbagai Tingkat Energi dan Protein Terhadap Performans Babi Grower Landrace. Fakultas Pasca Sarjana. UNPAD. Bandung.

Tillman, A. D., S. Reksohadiprodjo, S, Prawirokusumo dan S. Lebdosoekodjo. 1991. IlmuMakanan Ternak Dasar. Gadjah Mada University Press, Yogyakarta.

Yahya, R., W.A.A. Kaligis, J.F. Umboh, dan A. Najoan. 1999. Pengaruh penggunaan minyak kelapa dalam ransum babi grower terhadap kecernaan energi dan protein ransum. Skripsi. Fakultas Peternakan Universitas Sam Ratulangi Manado.

Wuisan, Ch. M.D.L., 1993. Pengaruh pemberian minyak kelapa dan minyak jagung serta kombinasinya dalam ransum sebagai sumber energi terhadap kecernaan ransum babi. Skripsi. Fakultas Peternakan Universitas Sam Ratulangi Manado. 